\title{
対地雷撃に伴って発生する水平電界の簡易評価法
}

\author{
正員道下幸志（静岡大）正員石井勝（東京大）
}

\section{Simplified Evaluation of Horizontal E-Field Associated with Cloud-to-Ground Strokes}

Koji Michishita, Member (Shizuoka University) Masaru Ishii, Member (University of Tokyo)

キーワート゚：雷撃，垂直電界，水平電界，大地導電率

\section{1.はじめに}

大地が有限な導電率をもつ場合に電流双極子が生じ る電界の計算には，厳密解に Sommerfeld 積分(1)が含 まれることから，雷放電路を双極子で置き換えて数值 計算する場合には膨大な時間が必要となる。このた め，多くの近似解が提案されており，雷撃点までの距 離が数 $\mathrm{km}$ 以内の場合には Norton 解(2)の精度が良い ことが示されている(3)。また, Zenneck の式(4)も近似 解の一つであり, 雷撃点までの距離が $16 \mathrm{~km}$ 以上の 対地雷撃により生じる電界波形では成立することが示 されている(5)。文献( 6 )では, 雷揧点までの距離が7 $\mathrm{km}$ の場合にもZenneckの式が成立すると報告され ているが, 水平電界の測定精度に問題がある。著者ら は, 垂直電界の混入が 1.4\%程度と測定精度が改善さ れた水平電界センサを用いて, 雷撃点までの距離が 5 $\mathrm{km}$ の垂直, 水平電界の同時計測を行い, 観測された水 平電界波形に基づいて，Zenneckの式が低周波にお いて問題があることを指摘した(》。文献 (7)ては雷撃点 までの距離を垂直電界波形から $2 \mathrm{~km}$ と推定したが, 後に雷鳴記録から $5 \mathrm{~km}$ であることが確認された

本報告では，垂直電界から水平電界を求める近似解 法を提案し，この解法の妥当性を検討する。

\section{2. 水平電界の計算手法}

大地面上に位置する大地に垂直な双極子の生じる垂 直抢よび水平電界の関係を，Norton 解から (2)の条 件のもとに(1)式のように近似した。

$$
\begin{aligned}
E h(f) / E v(f) & \\
& =\frac{z / D\left\{1+3 / j k D+3 /(j k D)^{2}\right\}-u(1+1 / j k D)}{1+1 / j k D+1 /(j k D)^{2}}
\end{aligned}
$$

ただし，

$$
\begin{aligned}
& z^{\prime} \ll D,\left|u^{2}\right| \ll 1 \cdots \ldots . \\
& u=1 /\left\{\varepsilon_{r}+\sigma / j 2 \pi f \varepsilon_{0}\right\}
\end{aligned}
$$

ここに, $k:$ 波数 $(=2 \pi f / c), c:$ 光速, $z$ : 観

測点地上高, $D:$ 双極子までの水平距離,

$z^{\prime}:$ 双極子地上高, $\varepsilon_{r}:$ 大地の比誘電率,

$\sigma:$ 大地導電率, $\varepsilon_{0}:$ 空気の誘電率

また，大地導電率による高周波成分の減衰を表す減 衰関数(Norton解に含まれる)は1と簡略化した。

(1)式の適用範囲を検討するために, 雷放電路の上限 $H$ をパラメータとして水平電界波形の計算を行った。 主放電電流波形は，波頭長 $2.0 \mu \mathrm{s}$, 波尾長 $78.0 \mu \mathrm{s} の$ 三角波で近似し， $100 \mathrm{~m} / \mu \mathrm{s}$ で地上面から大地に垂直 に隇衰なく進展すると仮定した。微小な双極子の生じ る電界を Norton 解から求め, それらを $z^{\prime}=0$ から $z^{\prime}$ $=H$ まで積分して得られる水平電界波形のピーク値 と, 前述の手法で計算された垂直電界から，(1)式掠 よび同式の右辺を $u$ とする Zenneck の式をラプラス

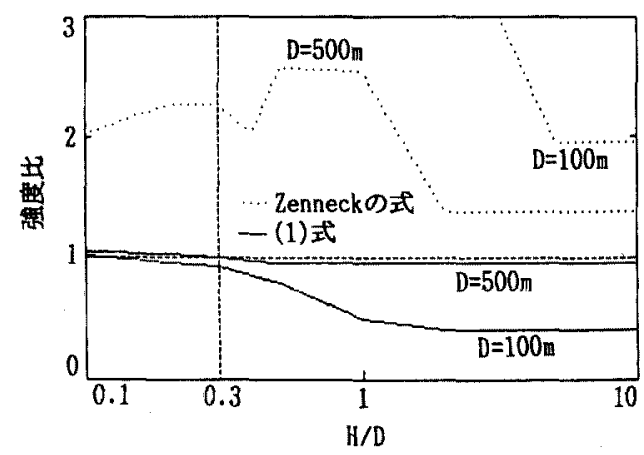

図 1 （1）式抢よびZenneck の式から計算される 水平電界のピーク值の Norton解加ら計算される 水平電界のピーク值に対する比

$\left(\sigma: 0.001 \mathrm{~S} / \mathrm{m}, \varepsilon_{r}: 10, z=0 \mathrm{~m}\right)$

Fig. 1. Ratios of peaks of horizontal elec. tric field waveforms evaluated by Eq. (1) or wavetilt formula to that evaluated by Norton's approximation. 


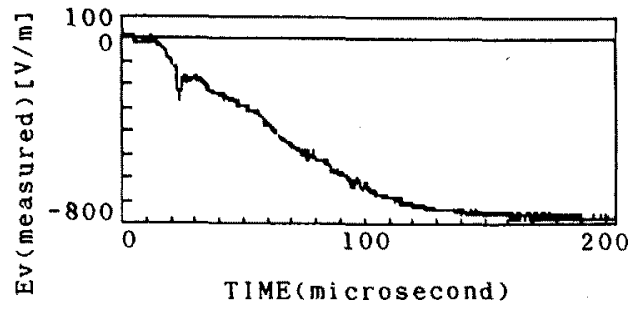

(a) 釷直電界

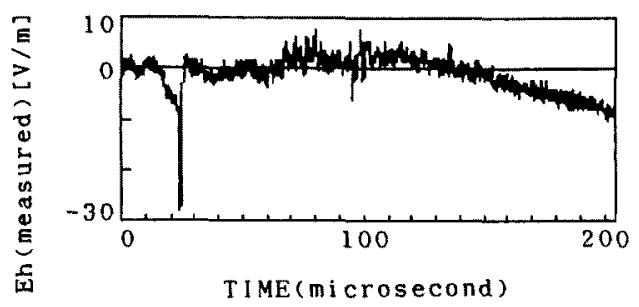

(b) 地上高 $1 \mathrm{~m}$ ○水平電界波形（実湖)

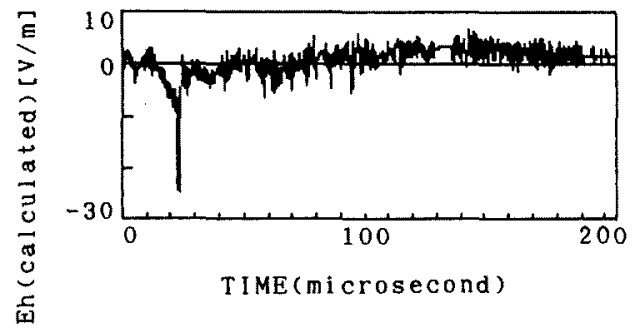

（c）今回提案した手法により計算された水平電界波形

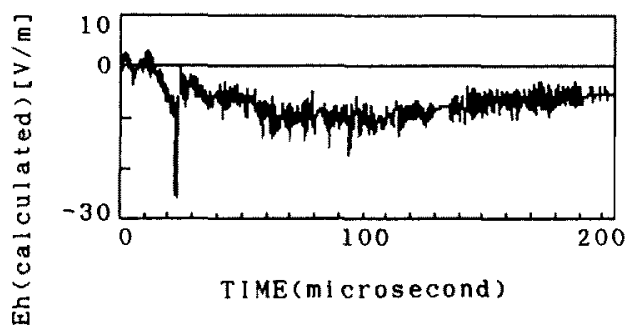

(d) Zenneck 0 式により計算された我平䉓界波形

困 $25 \mathrm{~km}$ 離れた対地雷軗に伴引垂直電界 (a)，测定された水平電界(b)，（1)式加ら 計算された水平電界 $(\mathrm{c})$, Zenneck 0 式 から計簘された水平電界波形 $(\mathrm{d})$

Fig. 2. Measured vertical (a) and horizontal(b) electric field waveforms, associated with a cloud-to-ground stroke at the distance of $5 \mathrm{~km}$, and horizontal electric field calculated from Eq. (1) (c) and that from "wavetilt formula"(6) $(d)$.

変換して, 時間領域で計算された水平電界波形のピー ク值の比較を行った結果を図 1 に示す。

$D=100 \mathrm{~m} て ゙ H / D<0.3$ の場合には，(1)式から
計算される電界波形と Norton 解から計算される水平 電界波形はよく一致しているが， $H$ が大きくなると 相違が生じ, (1)式では水平電界が過小に評価され る。

$D=500 \mathrm{~m}$ の場合には $H$ が大きくなってもピーク 值には 5\%程度の誤差しか生じないが，Dの増加に つれて水平電界の波尾部分が過小評価されるようにな る。

以上の検討から，(1)式は $D>100 \mathrm{~m} て ゙ は z^{\prime}<$ $0.3 D$ で適用可能と判断した。一方, Zenneckの式では, (1)式とは対照的に，水平電界を過大評価している。

\section{3. 実測波形との比較}

文献 (7)の実測された電界波形に(1)式扔よび Zenneckの式を適用して計算された水平電界波形を 図 2 で比較する。測定点の大地導電率わよび比誘電率 は， $0.00039 \mathrm{~S} / \mathrm{m}$ 抢よび 4 と推定されている(5)。両者 の計算結果では水平電界波形の波尾の部分の形状が異 なり，今回提案した手法では，120 $\mu \mathrm{s}$ 程度までは実測 とよく一致していることから，図 2 の波形の $120 \mu \mathrm{s}$ 以前の時間領域では， Z゙が $1.5 \mathrm{~km}$ 以下の双極子から 放射される電界が優勢であったものと推定できる。

一方で, $120 \mu \mathrm{s} よ り$ 後の部分では, 今回提案した手 法においても，測定された電界成分とは相違が生じて いる。これは，この時間領域の電界では地上高の大き い双極子からの寄与が大きくなることや，雷放電路の 傾きの影響などのためと考えられる。

最後に本研究を行うにあたり，多くの御協力をいた だいた東京大学生研北條準一博士，ならびに東北電 力 (株)関係各位に深く感謝の意を表します。

(平成 4 年 2 月 28 日受付)

$$
\text { 文献 }
$$

(1) J. Stratton: Electromagnetic Theory (1941) McGrawHill

(2) K. A. Norton: Proc, IRE, 25, 1203 (1937)

(3) A. Zeddam, et al. : Electromagnetics, 7, 541 (1987)

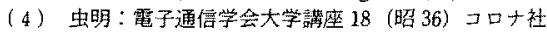

(5) 道下, 他: 平 4 電気学会全大, 1264

(6) E. Thomson et al.: J. Geophys. Res., 93, 2429 (1988)

（7）道下, 他: 慗学論 B, 110,986 (平 2-11)

(8) 道下, 他: 平 4 電気学会全大, 1263

道下幸志 (正負)

(平成 4 年 電学論 B, 112 巻 3 号, p. 251 参照)

\section{石井勝 (正員)}

(平成 4 年 電学論 B, 112 巻 3 号, p. 251 参照) 